Methods Cross-sectional study with secondary data from the 2013 Brazilian National Health Survey, with a representative sample of the Brazilian population, including 60202 individuals. Descriptive statistics were used to present the social and demographic variables and the occurrence of the outcome. Chi-square was performed to test differences between groups. Results A prevalence of MSD was 2.2 times higher in females compared to males (prevalence of $3.3 \%$ and $1.5 \%$, respectively). The prevalence of occupational accidents was $47 \%$ lower among women compared to men (prevalence of $1.4 \%$ and $3.1 \%$, respectively).

Discussion Although MSD and work accidents have a seemingly low prevalence in relative values, absolute numbers of cases are worrying, showing a non-favourable picture for working population health. Theses inequalities on health outcomes occurrences can be partially explained by the unequal way that men and women are inserted in Brazilian working market

\section{CAUSE-SPECIFIC SICKNESS ABSENCE BY OCCUPATION}

${ }^{1}$ Therese N Hanvold*, ${ }^{1}$ Karina Corbett, ${ }^{1,2}$ Petter Kristensen, ${ }^{1}$ Ingrid S Mehlum. ${ }^{1}$ National Institute of Occupational Health, Oslo, Norway; ${ }^{2}$ Institute of Health and Society, University of Oslo, Norway

\subsection{6/oemed-2018-ICOHabstracts.375}

Introduction To identify workers facing particular challenges related to occupational exposure and health is valuable, as work environment plays an important role in terms of sickness absence (SA) and return to work. Assessing vulnerable occupational groups related to SA may facilitate decision makers in terms of allocating resources and interventions. The aim of this paper was to assess cause-specific SA rates by occupation and evaluate occupational specific excess fractions for SA. Methods The source population was a Norwegian birth cohort (all 626928 live-born individuals born between 1967 and 1976). Individual records on physician-diagnosed SA spells lasting $>16$ calendar days were obtained from the Norwegian event database FD-Trygd. The incidence rate of SA was estimated annually during 2005-2009. SA with musculoskeletal and mental diagnoses, was estimated for 31 occupational groups classified by ISCO-88 on a 2-digit level. Excess causespecific SA was also estimated for each of the 31 occupations. All analyses were stratified by gender.

Result Workers in sales and service occupations and metal and machinery workers had the highest annual rates of musculoskeletal SA. Male metal and machinery workers had a $91 \%$ increased rate, compared to male corporate managers, while female workers in sales and services occupations had an $83 \%$ increased rate, compared to female corporate managers. For SA related to mental disorders, personal care workers had the highest rates among both men and women.

Discussion Occupation is an imprecise measure of work exposure and in the continued work on these data we will use a newly developed job exposure matrix to estimate the associations between specific physical and psychosocial exposures and cause-specific sickness absence by occupation.

\section{MINI BREAK INTERVENTION IN PREVENTING ASTHENOPIA AMONG DRAWING WORKERS USING STANDARD AND WIDESCREEN SIZE VDT AT CONSTRUCTION COMPANY IN JAKARTA}

B Hidayat*, T Rahayu, A Kekalih. Univercity of Indonesia, Indonesia

\subsection{6/oemed-2018-ICOHabstracts.376}

Introduction Astenopia has the effect of decreasing work productivity and health condition. Although the computer has not been proven to make permanent damage to the eyes but temporary discomfort due to tired eyes can reduce productivity. The impact is on lost working hours and reduced job satisfaction. In indonesia, In a diagnostic test of tired eye screening tool for office workers in north Jakarta, astenopia prevalence was found at $80 \%$. Asthenopia among drawing workers is becoming my attention because there are significant number of drawing workers as office workers in Jakarta, Indonesia and limited data regarding their health effect from their work Methods This is an experimental study with cross over design. The number of subjects who participated in this study were 66 participants. Intervention of no mini break and mini break were given to workers who used VDT size 4:3 and VDT size 16:9. Data was revealed from the difference of NPC before and after 4 hours of VDT exposure and 4 hours of exposure with a 15 min mini break after 2 hours of work to both groups (sub group of VDT 4:3 and VDT 16:9) using RAF (Royal Air Force) ruler.

Results The users of VDT size 4:3 have difference of NPC $2,89 \pm 1,11 \mathrm{~cm}$ in no mini break intervention and 1,42 $\pm 1,01 \mathrm{~cm}$ in mini break intervention. The users of VDT size 16:9 have difference NPC $3,02 \pm 1,04 \mathrm{~cm}$ in no mini break intervention and $1,41 \pm 1,10 \mathrm{~cm}$ in mini break intervention. The difference of convergence power between no mini break and mini break intervention for VDT size $4: 3 \quad(p=0.000)$ and size 16:9 users $(p=0.000)$ was statistically significant. There was no significant difference statistically in convergence power in no mini break intervention between VDT size 4:3 and size 16:19 users $(p=0,6251)$ and neither in mini break intervention between VDT size 4:3 and size 16:9 users $(p=0,9694)$.

Conclusion The convergence power is different significantly between working without mini break and with mini break in both of VDT users size 4:3 and 16:9. There is no diference significantly between VDT users size $4: 3$ and 16:9 in no mini break intervention as well as mini break intervention. This is probably because the measurement is only based on NPC and experimental limitations. It takes other parameters to measure asthenopia due to VDT usage as asthenopia is a sign of computer vision syndrome.

\section{TOTAL BURDEN OF PRESENTEEISM, ABSENTEEISM AND MEDICAL/PHARMACEUTICAL COST BY HEALTH RISKS}

Koki Kimura*, Tomohisa Nagata, Makoto Ohtani, Koji Mori, Masako Nagata, Shigeyuki Kajiki, Yoshihisa Fujino, Shinya Matsuda. University of Occupational and Environmental Health, Japan, Kitakyushu, Japan

10.1136/oemed-2018-ICOHabstracts.377 